Kotrbova, K., \& Majzlanova, K. (2021). Therapeutic Diary in Bibliotherapy (in Slovak). Problems of Education and Teaching in the Era of Digital Society. European Scientific e-Journal, 2 (8), 29-50. Hlučín-Bobrovníky: "Anisiia Tomanek" OSVČ. (in Slovak)

Kotrbová, K., Majzlanová, K. (2021). Terapeutický denník v biblioterapii. Problems of Education and Teaching in the Era of Digital Society. European Scientific e-Journal, 2 (8), 29-50. Hlučín-Bobrovníky: “Anisiia Tomanek” OSVČ.

DOI: $10.47451 /$ ped2021-01-004

The paper will be published in Crossref, ICI Copernicus, Academic Resource Index ResearchBib, J-Gate, ISI International Scientific Indexing, Zenodo, OpenAIRE, BASE, LORY, LUASA, ADL, eLibrary, and WebArchive databases.

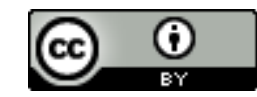

Kvetoslava Kotrbová, Doctor of Philosophy, Doctor of Philosophy Sciences in the fiel dof Nursing and Rehabilitation, Master of Public Health Management, Specialist for Therapeutic Pedagogy,

Department of Therapeutic Pedagogy, Pedagogy Faculty, Comenius University. Bratislava, Slovakia.

Katarína Majzlanová, Assistant Professor, Doctor of Pedagogy, specialist for Therapeutic Pedagogy, Doctor of Philosophy Sciences in the field of Therapeutic Pedagogy, Department of Therapeutic Pedagogy, Pedagogy Faculty, Comenius University. Bratislava, Slovakia.

\title{
Therapeutic Diary in Bibliotherapy (in Slovak)
}

Abstract: The authors deal with the writing of therapeutic diaries as part of clinical, developmental and preventive bibliotherapy. They inform about proven biological, psychological and social effects, examples of successful use in medical and pedagogical practice, basic principles, rules and conditions of writing, possible risks as well as the tasks of professionals accompanying individuals to such kind of therapy. They present bibliotherapy within the field of therapeutic pedagogy, which with a focus on helping a person in somatic, mental and social functions, in the improvement of quality of life and integration of the individual into society, has an essential role and importance. They describe their own experience with the application of therapeutic diaries as a tool for personal and professional growth of the university students preparing to work in the helping profession of therapeutic pedagogue during a period of predominantly on-line distance learning application for society-wide anti-epidemiological regulations. The collected and retrospectively analyzed feedback from the students showed that therapeutic diaries are also an effective preventive method for coping in difficult life situations when the possibility of physical verbal sharing of experiences with another person is limited, difficult, unavailable or may not be appropriate. The article points out the importance of promotion of therapeutic diaries for pedagogical and health professionals as a tool for processing emotionally stressful situations and experiences not only in children and adults with a focus on supporting their healthy development and life but also as a potential tool of one's psychohygiene in connection with the performance of their profession.

Keywords: therapeutic diary, receptive and expressive methods of bibliotherapy, expressive writing, clinical, developmental and preventive bibliotherapy, professional role in therapy process of writing.

Kvetoslava Kotrbová, Doktor filozofie, MPH, Špecialista na terapeutickú pedagogiku, Katedra liečebnej pedagogiky, Pedagogická fakulta, Univerzita Komenského. Bratislava, Slovensko.

Katarína Majzlanová, Doktor pedagogiky, Špecialista na terapeutickú pedagogiku, Katedra liečebnej pedagogiky, Pedagogická fakulta, Univerzita Komenského. Bratislava, Slovensko.

\section{Terapeutický denník v biblioterapii}


Abstrakt: Autorky sa v článku zaoberajú písaním terapeutických denníkov ako súčasti klinickej, vývinovej a preventívnej biblioterapie. Informujú o preukázaných biologických, psychologických a sociálnych účinkoch, o príkladoch úspešného uplatnenia v pedagogickej i zdravotníckej praxi, základných zásadách, pravidlách a podmienkach písania, možných rizikách ako aj o úlohách profesionála sprevádzajúceho jednotlivca rámci biblioterapie. Predstavujú biblioterapiu v rámci odboru liečebnej pedagogiky, ktorá so zameraním na pomoc človeku pri somatických, psychických a sociálnych funkciách, pri zvyšovaní kvality života a začlenenia jednotlivca do spoločnosti, má podstatnú úlohu a význam. Popisujú vlastnú skúsenost' s uplatnením terapeutických denníkov ako nástroja osobnostného a profesionálneho rastu u študentov univerzity pripravujúcich sa na prácu $\mathrm{v}$ pomáhajúcej profesii liečebného pedagóga počas obdobia prevažne on-line dištančného vzdelávania pre prijaté celospoločenské protiepidemiologické opatrenia. Zozbierané a retrospektívne analyzované spätné väzby študentov ukázali, že pri terapeutických denníkoch ide aj o účinnú preventívnu metódu na zvládanie náročných životných situácií, ked’ je možnost' fyzického verbálneho zdielania významných zážitkov s inou osobou limitovaná, st’ažená, nedostupná alebo by nemusela byt' vhodná. Článok poukazuje na význam propagácie terapeutických denníkov u pedagogických a zdravotníckych pracovníkov ako nástroja na spracovanie emočne zát’ažových situácií a zážitkov nielen u detí a dospelých so zameraním na podporu ich zdravého vývinu a života, ale aj ako potenciálneho nástroja vlastnej psychohygieny v súvislosti s výkonom ich profesie.

Klücové slová: terapeutický denník, receptívne a expresívne metódy biblioterapie, expresívne písanie, klinická, vývinová a preventívna biblioterapia, úloha profesionála v terapeutickom procese písania.

\section{Skratky:}

MKCH - Medzinárodná klasifikácia chorôb.

MKF - Medzinárodná klasifikácia funkčnej schopnosti, dizability a zdravia.

\section{Úvod}

Ciel'avedomé uplatňovanie terapeutických účinkov čítania a písania je pravdepodobne rovnako tak staré ako história rôznych systémov písma. Vel'ké diela - eposy rôznych národov a prehistorická poézia, liečivé piesne a čítanie textov od našich vzdialených predkov sú s nami dodnes, pretože sú integrálnou súčast'ou našej literárnej aj hudobnej kultúry a folklóru.

Písanie denníkov máme najčastejšie spojené s pubertálnym a adolescentným obdobím života človeka. Vplyvom prirodzených výrazných a nerovnomerných biologických zmien dochádza v tomto vývinovom období aj ku zmenám v psychickej oblasti. Zvýšená emocionálna vnímavost', prehlbovanie citového života, zvýraznená hĺbka a intenzita prežívania, živšia predstavivost' a hladanie a rozvoj vlastnej identity ako prirodzené javy v tomto vývinovom období prirodzene vedú aj k zvýšenému záujmu o umenie, transcendentálne, snahu o básnické a iné umelecké sebavyjadrenie, ako aj o vedenie denníkov ako jednej z možností na zvládnutie prebiehajúcich zmien. Denník však môže rovnako dobre pomáhat’ aj v iných vývinových obdobiach človeka, rovnako v dospelosti, ako aj v detstve.

Existujú rôzne druhy denníkov. Faktografické, ktoré sa sústred’ujú na strohý popis vonkajších udalostí, fakty a heslá s jednoduchým ciel'om ich iba zachytit' alebo popísat'. Ďalej sú denníky spomienkové, ktorých ciel’om je zachytenie a pripomenutie významných osobných alebo rodinných udalostí, prípadne významných udalostí určitej skupiny osôb alebo organizácie (rovesníckej skupiny, triedy, školy, klubu a podobne), ktoré často mávajú podobu kroniky. 
Existujú denníky motivačné, určené na zaznamenávanie stanovených ciel’ov spravidla výkonového charakteru a pokrokov v nich. Existujú denníky, ktoré zachytávajú informácie, ktoré pre nás majú istú hodnotu, za čo sme vd’ační a čo sa podarilo. Existujú denníky čitatel’ské na zachytávanie zaujímavých citátov, výpiskov z kníh. A existujú tiež denníky terapeutické, ktorých účelom je zachytenie najsúkromnejšçch individuálnych myšlienok, pocitov, emóciú, túžob, výżnamov a snov jednotlivca.

Písanie terapeutických denníkov v terapeutickej praxi historicky začínalo zapisovaním snov. Rovnako ako krásna literatúra prostredníctvom jazyka, tak aj sny prostredníctvom obrazov, komunikujú metaforické významy, ktoré môžu byt' individuálne vel'mi významné. Prvé denníky v klinickej praxi využívali psychoanalytickí psychoterapeuti. Pacienti si do nich zaznamenávali svoje sny a na stretnutiach potom o nich spoločne s terapeutom diskutovali. Sprostredkovane teda slúžili ako bohatý terapeutický materiál. Využitie denníkov na monitorovanie správania a neskôr aj pocitov a myšlienok, je však hlboko zakorenené v tradícii behaviorálnej terapie. Denníky v rámci klinickej psychológie preto nie prekvapujúco spopularizovali práve behaviorálni terapeuti (Thiele a kol., 2020).

V tomto článku prinášame pohlad na možnosti vedenia terapeutických denníkov na riešenie aktuálnych problémov $\mathrm{v}$ akomkol’vek vekovom období s osobitným s podporou liečebného pedagóga.

\section{Liečebnopedagogicky orientovaná biblioterapia}

Pojem biblioterapia je známy prevažne v spojitosti s medicínou, ako metóda v psychoterapii, ktorá sa využíva najmä pri práci s psychiatrickými pacientmi. Biblioterapia má úzke prepojenie aj s inými vednými odbormi (psychológia, pedagogika, sociológia, liečebná pedagogika, špeciálna pedagogika, literárne umenie, knihoveda, ...).

H. Hartlová a P. Hartl, definovali biblioterapiu ako metódu využívajúcu liečebné alebo podporné účinky čítania (Hartlová a Hart, 2009). M. Howie vymedzil klinickú a vývinovú biblioterapiu. Klinickú biblioterapiu chápe ako metódu intervencie, pomoci poskytovanej pacientom s vážnym emocionálnymi alebo behaviorálnymi t’ažkost’ami (Howie, 1988). Vývinovú biblioterapiu považuje za podpornú metódu pri riešení krízových situácií, napomáhajúcu sebarozvoju jednotlivca, ktorá slúži na uspokojovanie jeho životných potrieb. P. Svoboda popisuje biblioterapiu ako psychosomatickú, psychorelaxačnú, edukačnú, ako tvorivé písanie, písanie denníka, naratívnu, lyrickú, polyestetickú a virtuálnu (Svoboda, 1988).

Biblioterapiu v liě̌ebnej pedagogike chápeme ako cielavedomé, systematické liečebnovýchovné pôsobenie jednotlivými zložkami literárneho prejavu u ohrozených, chorých, narušených, zdravotne znevýhodnených jednotlivcov. Biblioterapia ako metóda komunikatívneho charakteru má podnecujúci vplyv na verbálny prejav klientov a môže slúžit' ako interakčný činitel', stimulátor emocionálneho, etického a sociálneho vývinu. Biblioterapeutická intervencia môže u človeka v zložitej životnej situácii sprostredkovat' vhl'ad do jeho problémov, možností ich riešenia a životných perspektív (Majżlanová, 2018:193).

Z hl'adiska prístupu ku klientovi rozoznávame klinickú, edukativno - bumanistickú a behaviorálnu biblioterapiu. Klinická biblioterapia sa chápe ako metóda intervencie, pomoci, poskytovanej pacientom so psychickými a emocionálnymi problémami, $\mathrm{v}$ pedagogicko-psychologických poradniach, $v$ zariadeniach ústavného typu pre postihnutých jednotlivcov, kde je biblioterapia 
indikovaná ako podporná terapia popri farmakologickej liečbe a psychoterapii. Tzv. edukativno bumanistická biblioterapia slúži ako intervenčný program v školách, v detských domovoch, $\mathrm{v}$ domovoch dôchodcov, liečebnovýchovných zariadeniach, $\mathrm{v}$ špeciálnopedagogických poradniach, $\mathrm{v}$ kluboch a organizáciách $\mathrm{v}$ rámci občianskych združení a nadácií. Behaviorálna biblioterapia sa uplatňuje $\mathrm{v}$ ambulanciách a centrách pre liečbu drogových závislosti, $\mathrm{v}$ nápravnovýchovných zariadeniach, pre osoby vo výkone trestu, v diagnostických centrách pre deti a mládež (Majzlanová, 2017:0).

Pri biblioterapii zameranej na jednotlivca hovoríme o individuálnej biblioterapii. Uplatňujeme ju vtedy, ked' klient nie je pripravený pôsobit' v skupine alebo si riešenie jeho problému vyžaduje osobitný prístup. Skupinová forma biblioterapie pôsobí ako motivačný a aktivačný činitel pri práci s klientom, vytvára priaznivé podmienky na prekonanie emocionálnej izolácie, navodzuje snahu vzájomného porozumenia. Hromadná forma biblioterapie je vel’mi zriedkavá a väčšinou sa kombinuje so skupinovou alebo individuálnou formou biblioterapie. Uskutočňuje sa napríklad prostredníctvom rozhlasu v danom zariadení pri vysielaní literárneho diela. Jednotlivé formy biblioterapie sa kombinujú. Počas hromadnej alebo skupinovej formy biblioterapie môže niektorý z klientov po čase potrebovat' individuálny kontakt s terapeutom a naopak, klient v individuálne forme biblioterapie sa môže po určitom čase zaradit’ do skupiny (Pilarčíková-Hýblová, 1997:24; Rothschild, 2007).

$V$ rámci ciel'ov sa u klientov zameriavame na nadviazanie kontaktov, odreagovanie napätia, rozvoj zdravébo sebavedomia, sebarealizácie, spolupráce, rozvoj tvorivosti a predstavivosti, poskytovanie záą̧itku úspešnosti, vąbudenie či prehĺbenie záujmov, roqvíjanie komunikácie, schopnosti nábladu na svoju situáciu, bodnoty, problémy, odpútanie sa od problémov. V liečebnopedagogicky orientovanej biblioterapii si stanovujeme globálne ciele, ktoré vyplývajú z aktuálnych problémov u klienta v oblasti správania a prežívania (u detí napríklad impulzívne správanie, problémy s adaptáciou na nové prostredie a pod., u dospelých klientov s emocionálnymi problémami pri zvládaní st’ažených životných situácií, ako je vážne ochorenie, posttraumatické stavy). V rámci uvedených ciel'ov sa zameriavame na sebapoznávanie, získavanie nových informácií a skúseností, ktoré v mnohých prípadoch majú pozitívny vplyv na správanie, prežívanie a vytváranie nových postojov. Pri konkrétnejšich cieloch sa zameriavame na plnenie čiastkových úloh pomocou funkcií literárneho textu, na základe cieleného výberu literárnych žánrov a pod. Pri mikrocieloch ide o identifikáciu konkrétnych prístupov, ktoré uplatňujeme pri dosahovaní záverečného ciela (Majælanová, 2017:8).

Zameriavame sa $\mathrm{v}$ nej na pochopenie, porozumenie a prijatie životnej situácie, v ktorej sa človek nachádza, nájdenie zdrojov zvládania, poskytnutie modelov správania, sprostredkovanie nádeje a nových životných kompetencií, pozitívneho emocionálneho a estetického zážitku, vedenie $\mathrm{k}$ hlbšiemu zmyslu a pozitívnym životným hodnotám v rozšírenom holistickom biopsycho-socio-spirituálnom koncepte ponímania zdravia človeka prostredníctvom literárnych diel (Majølanová, 2018).

Predmet biblioterapia - sa okrem arteterapie, dramatoterapie, ergoterapie, muzikoterapie, psychomotorickej terapie a terapie hrou - vyučuje na Katedre liečebnej pedagogiky Pedagogickej fakulty Univerzity Komenského od roku 1994. Študenti študijného programu liečebná pedagogika absolvujú 4 semestre teoretickej a praktickej výučby z biblioterapie ako súčast' celkového počtu 5000 hodín univerzitného štúdia v odbore liečebnej pedagogiky. 


\section{Terapeutické denníky ako súčast' expresívnej metódy biblioterapie}

$V$ biblioterapii už tradične rozlišujeme receptivnu a expresínn metódu biblioterapie. Pri receptínnej metóde biblioterapie ide hlavne o terapeuticko-výchovné a preventívne výchovné využívanie:

1) počúvania prednášaného alebo predčítaného literárneho diela alebo;

2) samostatného čítania literárneho diela.

Pri expresivnej metóde biblioterapie ide o terapeuticko-výchovné a preventívne výchovné uplatňovanie:

1) aktívneho umeleckého prednesu/recitácie alebo roaprávania príbehov, rozprávok, básní, atd'.;

2) pisania ako takého až aktívnej literárnej tvorby vždy $\mathrm{v}$ rámci vopred identifikovaných terapeuticko-výchovných ciel’ov (Kotrbová a kol., 2019).

Súčast'ou každej biblioterapie je roz̧hovor, dialóg, vysvetlovanie, skupinová diskusia, alebo iná forma interakcie s terapeutom, ktorej primárnym ciel’om je poskytovanie spätnej vä̊by, facilitácia, podpora a sprevádzanie procesu poznávania.

Pri uplatnení receptívnej metódy biblioterapie technikou čítania - uplatňujeme čítanie ret'azové, spoločné, sólové, čítanie vo dvojici a predčítavanie textu. Z pohl’adu funkčnosti rozoznávame čítanie informačné, kritické a tvorivé. Ciel'om informačnébo čítania je zoznámit' čitatel'a s daným textom a získat' nové informácie. Pri kritickom cìtaní je klienti vyjadrujú k textu svoje vlastné stanovisko, názor. Tento prístup sa ukázal ako vhodný najmä u detí v pubertálnom veku a u niektorých dospelých klientov. Tvorivé čitanie je príležitost'ou pre klienta dokončit' dej literárneho textu inak, zmenit' zvrat deja a podobne a tým sa konfrontovat' so svojou životnou situáciou (Obert, 1980).

Pokial ide o expresívnu metódu biblioterapie súčasní autori zarad’ujú terapeutické denníky medzii tradičné a známe metódy expresivnej biblioterapie (Svoboda, 2013:47; Majそlanová, 2017:32; Kovácová a Valešová-Malecová, 2018:11), ku ktorým sa okrem písania terapeutických denníkov zarad’uje aj rozprávanie príbehov, recitácia alebo umelecký prednes uplatňovaný na základe vopred identifikovaných terapeuticko-výchovných ciel'ov. Patrí sem aj písanie listov - literárnemu hrdinovi, autorovi diela, sebe alebo inej dôležitej osobe, tvorivé písanie - teda tvorba kratších alebo dlhších umeleckých literárnych útvarov - parémií, poézie, prózy alebo divadelných hier, písanie výpiskov citátov $\mathrm{z}$ literárnych diel alebo zaznamenávanie zatial písomne nezachytených slovesných umeleckých diel, písanie čitatel'ských ohlasov a čitatel'ských denníkov, tvorba textových alebo textovo-obrazových koláží, komixov a podobne (Majzlanová, 2017; Svoboda, 2013; Majzlanová, 2005). Ide o všetky také činnosti, kde je recipient vedený k aktívnemu spracúvaniu materiálu slovesného charakteru.

V zahraničnej odbornej literatúre [1] sa písanie terapeutických denníkov zahŕňa do skupiny podporných prístupov označovaných súhrnne ,expressive writting "a hoci vo svojej podstate každé písanie je expresívne (vždy je zámerom pisatel’a niečo - to express - vyjadrit', v tomto prípade slovne), týmto slovom sa v porovnaní s inými prístupmi (ako napríklad „,reative writing ") označuje, že nejde iba tak o akékol’vek slovné vyjadrovanie alebo popisovanie - racionálne alebo reportážne faktografické alebo iné obdobné - ale hlavne a v prvom rade o (seba)odhal'ovanie, vyjadrovanie a popisovanie vlastných pocitov, emócií, túžob, myšlienok, významov a hodnôt.

V literárnom umení bývame niekedy svedkami pretavenia pôvodne súkromných a dôverných zápiskov, poznámok a úvah vedených $\mathrm{v}$ podobe denníkov do neskoršej podoby 
literárnych diel. Za všetky spomeňme celosvetovo najznámejší publikovaný denník s rovnakým názvom autorky aj diela Denník Anny Frankovej, ktorý mal najskôr vo svojej podstate podobu terapeutického denníka a neskôr ho - na základe publikovanej verejnej výzvy dánskeho Slobodného rádia Oranje vysielajúceho z Vel’kej Británie aby občania poskytli svoje denníky pre povojnovú zbierku na historické účely - Anna Franková začala prepisovat’ do podoby knihy (Shemesh, 2016).

$\mathrm{Na}$ zabezpečenie skutočne terapeutickej povahy denníka je však potrebné jednoznačne rešpektovat' zásadu, že terapeutický denník nie je určený na čítanie nikomu inému ako jeho pisatelovi (Rainwater, 1993:91). Preto je na dôverný privátny charakter terapeutického denníka potrebné klást' od samého začiatku náležitú pozornost'. Vysvetlit' klientovi dôvody takéhoto zamerania vrátane jeho priebežného vedenia k uskutočneniu všetkých potrebných a nevyhnutných krokov a opatrení na ochranu denníka pred nechceným oboznámením sa s jeho obsahom zo strany inej osoby (Pennebaker, 2013:12-13). Aj ked' by to malo byt' za cenu zaobstarania trezora s kódom, do ktorého bude denník vložený, aby bol chránený. To samozrejme, nevylučuje možnost' neskoršieho spracovania zápiskov z terapeutického denníka do umeleckej literárnej podoby, ak by si to osoba neskôr takto priala. Avšak umelecký literárny zámer nemá byt' v popredí.

Pre naplnenie terapeutických zámerov je preto v prvom rade zo strany sprevádzajúceho profesionála potrebné osobu inštruovat' a podporovat' $\mathrm{v}$ zabezpečení takých podmienok, aby pri písaní denníka mohol byt' pisatel' maximálne úprimný, slobodný a otvorený blavne sám pred sebou aj vo vel'mi intímnych zále žitostiach. Hlavne $\mathrm{v}$ takých, o ktorých sa môže inak sám domnievat', že o nich z rôznych dôvodov - či už sú dané výchovou, kultúrou, religióznym pozadím alebo v celoživotnom procese inak zvnútornenými presvedčeniami alebo hodnotami - nemôže alebo nie je vhodné hovorit', alebo že by očakávaná reakcia inej osoby, s ktorou by obsahy boli komunikované mohla byt' málo podporná, respektíve by dokonca mohla predstavovat' riziko d’alšej zát'aže, ked' by osobu mohla za jej zážitky alebo postoje k im začat' odsudzovat' (Pennebaker, 2013:12, 15).

Forma, miesto a čas sú taktiež vel’mi dôlę̧ité, pretože už tie reprezentujú individuálne významy. Podl'a odborníkov je vhodné osobe sprostredkovat' nasledovné inštrukcie (vol'ne upravené podl'a J.A. Rainwater, J.W. Pennebacker,) (Rainwater, 1993; Pennebaker, 2013):

- Vyhl’adajte doma, kúpte alebo vyrobte si pekný zápisník! Dajte si záležat', aby sa Vám páčila jeho farba, vyhovovala jeho vel'kost', atd'. Ak vám to vyhovuje, môžete písat' aj na vol'né listy papiera.

- Pokial' nemáte fyzické obmedzenia, uprednostnite pero a papier - píšte rukou! Aj ked’ je k dispozícii množstvo technických pomôcok - diktafóny, počítače príp. iné, písanie na papier máva omnoho osobnejší a emocionálnejší význam ako t’ukanie písmen na klávesnici alebo displeji.

- Nájdite si pokojné, prijemné miesto, kde máte súkromie - v parku, doma v izbe, v knižnici - skrátka kde vás nikto nebude rušit'.

- Vytvorte si rituál písania - zoberte si oblúbené pero, prineste si oblúbenú šálku.

- Záznamy si datujte - deň, mesiac, denná doba, rok, miesto.

- Nájdite si vhodnú dobu na písanie, ktorá ám osobne najviac vyhovuje: Môže to byt' skoro ráno, ked' ste ešte nevstali z postele, čo vám možno umožní všimnút' si a zapísat' aj sny, alebo budete potrebovat' sa najskôr osprchovat' a najest', aby ste si vyjasnili myšlienky pred ich napísaním. Väčšine l’udí však vyhovuje písanie na konci pracovného dňa, kedy už je 
väčšina povinností súvisiacich s prácou alebo chodom domácnosti zabezpečených. Možno že vám však bude vyhovovat' iná čast' dňa, dovol'te si aj v tomto slobodu vyskúšat' rôzne možnosti. Dôležité však je, aby ste mali k dispozícii ešte nejaký vol’ný čas na spracovanie myšlienok po napísaní.

- Píste v 1. osobe jednotnébo čisla! Píste súvisle ber.prerusovania.

- Zapisujte si myšlienky, obrazy, l’udí, zvuky/hudbu, vône, miesta, mená, názvy, výroky, citáty, básne, emócie, pocity, zážitky, skúsenosti, významy, sl’uby, presvedčenia, túžby, priania, rozhodnutia, sny... čokol'vek, čo na Vás silno zapôsobi (ako napriklad: Ked'vám niekto vel'mi „ubližri." A - ako ste k. tomu pripadne prispeli sami. Ked”ste nabnevani. Ked'ste smutni. Ked” sa niečobo obávate. Ked'sa nieč́omu vybýbate. Ked'potrebujete preskúmat' svoj vzt'ah k niekomu alebo niečomu. Ked' potrebujete preskúmat', pripadne żmenit' nejaké svoje staré presvedčenie. Ked' sa zamilujete. A do ro najvä̈ršich detailov. atd.).

- Píšte najmenej 15 minút a najmenej 4-5 dní- nemusia íst' súvisle za sebou!

- Môžete písat’ raz denne, týždenne, mesačne - nemalo by to však byt' d’alšie „mal by som“.

- Snažte sa zapísat' co najviac pocitov, každý jednotlivý detail, avšak hlavne čo najviac dôležitých detailov. Skúste to co najuýstižnejšie popisat?.

- Môžete si denník dopĺn̆at' o výroky, kresby, rôzne materiály, fotografie, môžete experimentovat' s poéziou, atd', ktoré situáciu vystibujú.

- Ak aj máte pocit, že nemáte myšlienky, pocity, nápady, iba tak pozorujte a niečo sa iste objaví.

- Pokojne píšte o tom istom znova, ak potrebujete!

- Ak o niečom nechcete písat', nemusíte; píšte o niečom inom.

- Nezaoberajte sa pravopisom a opravovaním gramatických chýb!

- Dajte si zakaždým čas na myšlienky „po napisani“. Aspoň 10 minút. Porovnajte, ako sa ste sa cítili pred a ako sa cítite po napísaní. V čom je to iné?

- Ak sa bezprostredne po písaní cítite horšie - v malom percente prípadov je to normálna reakcia - avšak ak dlhodobejšie pretrvávajú napríklad depresívne alebo sebadeštruktívne myšlienky, alebo sa vyskytuje nejaké iné nežiadúce alebo zat’ažujúce správanie, potrebujete s niekým hovorit' a je čas na vyhl'adanie a kontaktovanie odborníka.

- Po čase pre myšlienky „po napísani“ nezabudnite denník odlǒ̌it’ na bez̧pečné miesto, kde k nemu nebude mat' prístup nikto iný.

- Nebojte sa vracat' a čítat' si, co ste zapisali. Skúste vnimat', či je téma/ situácia stále aktuálna, alebo sa Vám ju podarilo vyriešit'. Čo sa zmenilo, ako? Čo sa Vám podarilo? Ako sa to udialo?

- Ak potrebujete, môžete sa po dopísaní celého denníka rozhodnút' denník odložit', ale môžete sa rozhodnút' ho neskôr aj roztrhat' alebo spálit'. O tejto záležitosti sa však nikdy nerozhodujte $\mathrm{v}$ hneve.

Písanie terapeutického denníka je spôsobom starania sa o seba. Je to miesto a čas pre seba, na rýchle odreagovanie, odventilovanie, oslabenie sily negatívnych pocitov a vysporiadanie sa s nimi, na orientáciu v prelomových vývinových situáciách alebo t’ažkých životných obdobiach. Umožňuje komunikáciu vtedy, ked’ práve nie je alebo nemôže byt' niekto podporný fyzicky nablízku. Sebapozorovanie s písaním súvisiace umožňuje jednak odpútanie sa od emočne zat’ažujúcich obsahov - ich odloženie na papier, čo by sa dalo prirovnat' k ,pisaniu pre útechu“, ako aj posilňovanie obohacujúcich obsahov ako akési ich „opakované zhmotnenie“, čo by sa dalo prirovnat' k „pisaniu z prebytku"(Rainwater, 1993:97). 
Písanie takéhoto denníka má vytvorit’ podmienky pre získanie náhl’adu bud' bezprostredne po napísaní, alebo po neskoršom prečítaní pisatel’om a uvedomenie si významu. Priestor pre „strávenie života“, zamyslenie, meditáciu, porozumenie sebe samému, lepšie zvládnutie problémov, vytvorenie hodnotového rebríčka, posilnenie sebadôvery a sebaúcty, zistenie vlastnej vol'by alebo preferencií, zmeny uhla pohl’adu/perspektívy $\mathrm{v}$ konečnom dôsledku vedie $\mathrm{k}$ dosahovaniu plnšieho uvedomenia a na základe toho zodpovedného a zámerného rozhodovania a prevzatia plnej zodpovednosti za seba, zlepšovaniu zdravia ako aj lepšiemu bytiu a kvalite života.

Rovnako ako pri zapisovaní silných zážitkov a pocitov do terapeutického denníka, tak aj prípadnom zapisovaní snov či už do tohto alebo iného zápisníka, je dôležité oddelit fázu produkcie od hodnotenia. Odporúča sa všímat' si krajinu, l'udí, predmety - spájajúce, nezvyčajné, tajomné, silné, kontrastné predmety, slovné hračky, hry čísel, ktoré sa vo sne vyskytli. Pocity po prebudení, farby. Je potrebné si tiež všímat', čo v sne chýba. Aká je vo sne správa pre d’alší rozvoj? Je vhodné túto správu zredukovat' na pár slov. Odporúča sa zaoberat' sa tým, čo možno s odkazom/odporúčaním urobit' po jeho uvedomení po prebudení. Nadväzne je možné experimentovanie s kontextom, dokončením sna pomocou otázok ako napríklad. Ako by tento sen prirodzene skončil, keby nebol prerušený? Akých spojencov alebo pomôcky by ste si mohli, ak treba do sna privolat'/pritiahnut' na pomoc? Čo by mohlo byt' inak? Ak nemáte sny, aký sen by sa Vám mohol snívat’? Ako sa cítite? Čo ste sa z toho naučili? (Rainwater, 1993:113).

Okrem uvedených sa v odbornej praxi vyskytujú aj denníky výskumné, ktoré sa v biblioterapii píšu na prianie výskumníka a majú prinášat’ informácie o skúsenosti klienta s priebehom liečby ako spätnú väzbu na uskutočňovaný terapeutický proces. Klient môže byt' identifikovaný, alebo môžu byt' výskumné denníky písané aj anonymne s tým, že osoba je uzrozumená, že terapeut bude ako výskumník tieto záznamy čítat’.

\section{3. Úlohy odborníka pri sprevádzaní klienta v procese písania terapeutického denníka}

Jednoznačnou výhodou písania terapeutických denníkov je skutočnost', že pacient môže z ich vedenia profitovat' aj v čase, ked’ terapeut nie je fyzicky prítomný. Ak je terapeutický denník použitý ako blavná technika expresívnej metódy biblioterapie, má potenciál znižovat' tlak na frekvenciu osobných stretnutí založených na verbálnom spracovaní zat’ažujúcich životných obsahov v priamom kontakte $\mathrm{v}$ rámci terapeutického vzt'ahu s terapeutom. Ak je terapeutický denník použitý ako doplnok alebo rozsirirenie už uskutočňovanej farmakologickej alebo inej nefarmakologickej liečby, prípadne diagnostiky alebo prevencie, má potenciál posilnit' účinok všetkých ostatných aplikovaných terapeutických intervencií.

Uvedené môže byt' čiastočne dobrou správou nielen pre pacientov, ale aj pre terapeutov v súvislosti so zabezpečením potrebného objemu a kvality zdravotnej starostlivosti pre zvýšné očakávania na zdravotnícke systémy z dôvodu postupne celosvetového predlžovania strednej dĺžky života a celkového starnutia obyvatel'stva v jednotlivých krajinách, d’alej pre stúpajúcu incidenciu a prevalenciu ochorení a výskyt komorbidít pri súčasnom z̧horšovaní dostupnosti potrebných zdravotníckych služieb pre limitované personálne, materiálno-technické, finančné a iné kapacity potrebné na zabezpečenie kvalitnej zdravotnej starostlivosti a ochrany a podpory zdravia (Kotrbová a kol., 2019). 
V profesionálne vedenej biblioterapii má mat' osoba $\mathrm{k}$ dispozícii možnost' proces písania, zaznamenané obsahy alebo potenciálne s písaním súvisiace problémy a otázky priebežne konzultovat' a niektoré dôležité záležitosti ešte prípadne aj vo verbálnej rovine spracovat' v kontakte a $\mathrm{v}$ spolupráci s terapeuticky vyškoleným pracovníkom. Môže to byt’ lekár, sestra, klinický alebo poradenský psychológ, liečebný pedagóg, klinický logopéd, prípadne iný odborník so vzdelaním na úrovni porovnatel'nej s vysokoškolským vzdelaním II. stupňa (magisterské, doktorské), ktorý počas vysokoškolského štúdia alebo nadväzujúceho d’alšieho profesionálneho vzdelávania zameraného na takúto prácu absolvoval potrebné vzdelávanie z oblasti mediciny - najmä anatómie a fyziológie, neurobiológie a neuropsychológie, d’alej z oblasti psychoterapie a samozrejme z oblasti biblioterapie $\mathrm{v}$ teoreticky a hlbšie prakticky orientovanom dlhodobom súvislom odbornom vzdelávani a výcviku.

Konzultácie s odborníkom majú okrem vhodného profesionálne vedeného dodatočného spracovania emočne zat’ažujúcich zážitkov priebežne zapisovaných do terapeutického denníka, tiež v osobnom kontakte zabezpečit' zabránenie preanalyzovávaniu tej istej záležitosti bez nachádzania akéhokol'vek riešenia, neproduktínemu písaniu o tej istej veci znova a znova bez nadobúdania potrebného vhl'adu, porozumenia a nachádzania východiska a napomôct' prípadnej korekcii v stratégii pisania, ak je to potrebné (Pennebaker, 2013:14).

Úlohou liečebného pedagóga je $\mathrm{v}$ prvom rade byt' bezpečnou osobou pre zdiel’anie obsahu denníka a pocitov, problémov, vhl'adov a iných skúseností pri jeho písaní; sprievodcom v prehlbovaní sebarozvoja a sebapoznania; katalyzátorom/podpornou osobou pri dodatočnom spracovaní obsahov, ktoré zostali nespracované alebo nepovšimnuté; pomocníkom pri formulovaní ciel'ov osobnostného rozvoja/terapeutických ciel’ov, definovaní priorít, škálovaní ich významu (na začiatku, počas a po uskutočnení zmeny); iniciátorom rozširovania poznania a kalibrácie zmeny napríklad otázkami „Čo ste si všimli nové?“, „V čom je to iné?“, „Čo by ste ešte potrebovali?'“, podporovatel’om prerámcovania, formulácie nového pohl’adu a perspektívy ako aj ukotvenia zmeny.

\section{Zdokumentované biologické, psychologické a sociálne účinky písania terapeutických denníkov}

V súčasnosti sa terapeutické denníky používajú nielen ako metóda psychoterapeutickej práce na psychiatrických a psychoterapeutických oddeleniach alebo ambulanciách nemocníc teda nielen pri liečbe duševných ochorení (vrátane liečby alkoholizmu a iných látkových alebo nelátkových závislostí, ktoré sa tiež nachádzajú medzi diagnózami patriacimi do oblasti psychiatrie), pri liečbe traumy (Pennebacker, 2004), ako aj v šrišej klinickej praxi - ako napríklad pri liečbe astmy a reumatiodnej artritídy (Indroop, 2019), liečbe bolesti (Thiele a kol., 2020), liečbe onkologických ochorení (Moor a kol., 2020), kardiovaskulárnych ochorení (Manæoni a kol., 2011), ale napríklad aj pre redukcii úzkosti a stresu v súvislosti s tehotenstvom (Quian a kol., 2020). Na rovnaký účel možno terapeutické denníky uplatnit' aj v liečebnej pedagogike pri riešení zat’ažujúcich životných situácií u detí a dospelých alebo pri ich vedení k nadobúdaniu nových životných kompetencií.

Zdokumentované výskumy informujú nielen o už dávnejšie známych meratel'ných psychologických úcinkoch vedenia terapeutických denníkov (Pennebacker, 2004; Pennebaker, 2013), ako sú okamžité a dlhodobé zmeny nálady, zníženie stresu, pocitov úzkosti, depresie, negativity, 
odmietania, hostility až agresivity, namiesto ktorých nastupujú pocity úlavy, zlepšenia, otvorenost' k prežívaniu pocitov št’astia, hlbšie poznanie, uvedomenie a múdrost'. Tieto sa prejavujú aj v správaní a sociálnych vzt'ahoch ako celkové upokojenie, otvorenost', priatel'skost', št'astie a zvýšená akceptácia druhých, v dôsledku čoho možno pozorovat’ zlepšenie prospechu v škole, zlepšenie pamäti, lepšiu kvalitu sociálnych alebo pracovných vzt’ahov, zlepšené procesy rozhodovania.

Odborné literárne zdroje informujú však aj o meratel'ných biologických účinkoch (Indroop, 2019; Pennebacker, 2004; Pennebaker, 2013), ku ktorým patrí zlepšená činnost’ imunitnébo systému (či už reprezentovaná zvýšením celkového počtu životaschopných okysličených červených krviniek alebo zvýšením počtu T-lymfocytov dôležitých pri boji s baktériami alebo vírusmi), zlepšenie funkčnej kapacity plúc u pacientov s astmou, zníženie bolesti u osôb s reumatoidnou artritídou, zlepšenie spánkového cyklu u osôb s rakovinou, zníženie hodnôt krvného tlaku u relatívne zdravých osôb, zníženie svalovej tenzie a potenia u osôb s vysokým krvným tlakom a podobne.

Ukazuje sa, že možnosti využitia terapeutických denníkov ako metódy podporujúcej ozdravný proces pacientov $v$ ostatných klinických disciplínach ako je pediatria, neurológia, klinická onkológia, kardiológia, geriatria, rehabilitácia, paliatívna medicína atd’. V krátkodobej alebo dlhodobej zdravotnej starostlivosti o pacientov, sú limitované iba otvorenost'ou a pripravenost'ou zdravotníckeho personálu túto metódu začat' používat'. A to bez ohl'adu na to, či ide o podporu zdravia v rámci stanovenej lekárskej diagnózy podl’a $\mathrm{MKCH}$ alebo (iba) v rámci funkčnej poruchy, ktorá sa ešte zatial' nemusela vždy prejavit' poškodením zdravia na somatickej úrovni v zmysle klasifikácie MKF.

Americký psychológ James W. Pennebaker, ktorý pôsobí ako profesor na Univerzite v Austine v Texase a ktorý už viac ako 20 rokov používa metódu, pri ktorej od človeka nechce nič viac iba to, aby položil pero na papier a písal, považuje sa za priekopníka v oblasti expresívneho písania a ktorý je aj autorom niekol'kých kníh venovaných tejto téme (Brov 2012), popisuje skutočne pozoruhodné výsledky z vlastných výskumov.

V prvej zo spomínaných štúdií (publikovanej v roku 1986), ktorú realizoval počas 4 rokov s 3 testovanými skupinami študentov:

1) ktorí si zapisovali emočne silné zážitky;

2) ktorí mali popisovat' priebeh udalostí bez zaoberania sa emóciami;

3) ktorí si nepísali žiadne denné záznamy zistil, že v skupinách študentov, ktoré sa zaoberali svojim emočným svetom, navštevovali lekára pre rôzne ochorenia (respiračné, infekcie, bolest' hlavy a podobne) o 43\% menej často ako študenti zaoberajúci sa záznamami bez zaznamenávania emócií (Pennebacker, 2004:6).

V druhej ním realizovanej štúdii, ktorej sa zúčastnili osoby s identifikovanou traumou z detstva, ktorá sa udiala do ich 17 rokov veku ako sú strata domova, sexuálne traumy všetkých druhov, smrt' blízkej osoby, prírodné katastrofy, rozvod rodičov, fyzické zneužívanie a podobne (n=157), o ktorej nemali mo:̌nost' hovorit' alebo písat', navštevovali svojho všeobecného lekára pre rôzne ochorenia $2 x$ častejšie ako osoby z kontrolnej skupiny bez traumy $z$ detstva $(n=310)$ a $0,5 x$ castejš ako osoby s traumou $\mathrm{z}$ detstva $(\mathrm{n}=165)$, ktoré ale o nej mali možnost' hovorit' alebo písat' (Pennebacker, 2004:4-5).

V novšom vydaní tej istej publikácie z roku 2013 (Pennebaker, 2013:9-10) autor popisuje aj výsledky projektu z roku 1994 s mužmi stredného veku, ktorí boli neočakávane prepustení z ich 
zamestnania $\mathrm{v}$ oblasti hi-tech technológií potom, ako pre rovnakú spoločnost' pracovali viac ako 15 rokov. Prvá skupina osôb písala o svojich najhlbších emóciách a myšlienkach týkajúcich sa straty zamestnania, kontrolná skupina písala o tom, ako trávi svoj čas. Po 8 mesiacoch písania si $52 \%$ z osôb z prvej skupiny zaoberajúcej sa najhlbšími emočnými emočné zážitkami a myšlienkami prostredníctvom písania našlo nové zamestnanie v porovnaní len s $20 \%$ osôb z druhej skupiny, ktoré sa zaoberali popisom ako počas dňa strávili svoj čas a to pri rovnakom počte realizovaných pracovných pohovorov. Počas projektu bolo zistené, že osoby z kontrolnej skupiny prejavovali počas pohovorov tol'ko nepriatel'stva, že osoby, ktoré s nimi viedli rozhovor, s nimi nechceli ako so spolupracovníkmi pracovat'. Písanie denníkov, v ktorých sa mohli zaoberat' emóciami, pomohlo osobám z prvej skupiny poslat' negatívne zážitky do minulosti a transformovat' ich a zmenilo ich to na osoby s otvorenou myslou a akceptujúcim prístupom $\mathrm{k}$ ostatným dospelým. Možno teda konštatovat', že písanie denníkov malo aj sociálne účinky.

\section{Výsledky uplatnenia prieskumu v liečebnopedagogickej praxi}

Povzbudení výsledkami štúdií a projektu vyššie uvedeného autora a majúc na pamäti, že písanie terapeutického denníka je vhodné použit' nielen ako:

a) metódu klinickej biblioterapie na zvládanie ochorení, funkčných porúch, zdravotných postihnutí, ohrození zdravia a životných problémov súvisiacich so st’aženými životnými okolnost'ami spôsobených zdravotným ohrozením, ochorením, postihnutím alebo funkčnou poruchou zdravia, alebo

b) metódu vývinovej biblioterapie zameranú na zabezpečenie primeraného zvládania životných úloh a problémov patriacich k danej vývinovej etape (Majz̧lanová, 2018; Svoboda, 2013; Kováčová a kol. 2018) a ktorú okrem vyššie vymenovaných zdravotníckych pracovníkov môžu úspešne vykonávat' aj špeciálni pedagógovia, poradenskí a školskí psychológovia, poradcovia, učitelia, vychovávatelia, sociálni pracovníci, prípadne knihovníci s príslušným vyššie popísaným vzdelaním na kvalifikované vykonávanie biblioterapie, ale v rámci prevencie aj ako

c) metódu osobnostnébo rastu a psychobygieny (Černá, 2019)

sme v letnom semestri akademického roka 2019/2020 ponúkli možnost' vedenia terapeutických denníkov skupinám študentom študijného programu liečebná pedagogika Pedagogickej fakulty Univerzity Komenského v Bratislave na prehĺbenie sebauvedomenia a zlepšovanie sebaregulácie a zároveň ako možnost' podpory ich osobnostného a odborného profesionálneho rastu. Kontinuálne prehlbovanie uvedomenia a sebaregulácie sú celoživotným nevyhnutným predpokladom dobrého výkonu práce v pomáhajúcich profesiách, medzi ktoré patrí aj povolanie liečebného pedagóga.

Celkove tri skupiny študentov $\mathrm{v}$ rôznych ročníkoch denného a externého štúdia študijného programu liečebnej pedagogiky ( $n=47$ ) obdržali na začiatku letného semestra na vyučovaní predmetu biblioterapia zadanie založit' a začat' si viest' terapeutický denník pri dodržaní zásad, pravidiel a podmienok, ktoré popisujeme vyššie v kapitole 2. spracované písomne do podoby powerpointovej prezentácie. Na konci semestra mali študenti vyučujúcej zaslat' fotografiu obalu/prvej strany denníka a písomne vypracovanú spätnú väzbu v rozsahu strojom písanej jednej strany A4, ako sa im pri vedení denníka darilo, čo zistili, všimli si alebo uvedomili, aké mali problémy, prípadne čo iné by ešte v súvislosti s vedením takéhoto typu denníka potrebovali 
vediet' alebo zdiel'at', alebo čo by ešte potrebovali. Študentom bola pri zadaní ponúknutá možnost' počas celého obdobia písania denníka v prípade potreby kontaktovat' vyučujúceho vrátane individuálnej konzultácie $\mathrm{k}$ jeho vedeniu.

Zhodou okolností bolo uvedené zadanie aplikované práve na začiatku obdobia zavedenia celospoločenských protiepidemiologických opatrení na ochranu pred vírusom Covid-19 vo februári 2020. $\mathrm{Na}$ zamedzenie šírenia vírusu bol obmedzený pohyb osôb na celom území Slovenska a vyučovanie sa odrazu začalo uskutočňovat' dištančne. S odporúčanými postupmi pre pedagógov poskytovat' vyučovanie on-line s využitím počítačových technológií.

Zo zozbieraných spätných väzieb od študentov vyplynuli rôzne odozvy, z ktorých 2/3 ( $n=30)$ by sme mohli označit’ ako výrazne pozitívne ako napríklad: „denník mi pomohol sa nezbláznit”“, „našla som si miesto a čas pre seba a mám sa komu vyrozprávat"“, „,pomohlo mi to nájst' negatívne pocity pod povrchom a vidiet' samu seba z novej perspektívy“, „začala som vnímat' viac vecí“, „pomáha mi to“, „nadchlo ma to“, „zatial’ nepozorujem účinok, ale prijemné“, „pomohlo mi to zvládnut' konflikt v rodine“, „,najprv som nechcela, ale potom ma to začalo tešit"“, „potvrdzujem, že to písanie fakt pomáha“, „zostala som s postihnutým diet'at'om sama doma, zaviedla som si ho, potom aj moja dcéra a pomáha“, „som sama doma s det'mi a pomáha“, „používam denník aj súkromne, aj vo svojej práci s det’mi na onkologickom oddelení a odporúčam".

Niektorí študenti potrebovali viac času na začatie z dôvodu problémov so zabezpečením ochrany denníka pred neželaným prečítaním zo strany inej osoby $(n=10)$. Niektorí uvádzali, že si denník už aj predtým viedli a prestali, alebo si denník už viedli a stále vedú ( $\mathrm{n}=12)$, ale nové zadanie im pomohlo to skúsit' trocha inak, čo popisovali ako napríklad „dostala som nové podnety“, „nevedela som ako znova začat' a teraz konečne prišiel ten impulz“, „najprv som nechcela, bolo to depresívne, ale potom ma to bavilo“, „radšej kreslím ako píšem, ale vyskúšala som a ok“, „vel'mi som nechcela písat', ale napokon som začala, až ma to začalo bavit', budem pokračovat"“, „,predtým som si denník písala na písacom stroji, teraz som skúsila ručne a je to lahšie“, „začala som si denník písat' minulý rok kvôli problémom na odbornej praxi, párkrát mi v ich zvládaní denník vel’mi pomohol“.

Iba v 4 prípadoch bola zaznamenaná odozva, ktorú by sme mohli označit' za relatívne a to zdôrazňujeme - skutočne iba relatívne - negatívnu: „začala som, ale nebudem pokračovat', lebo radšej kreslím alebo lepím obrázky“, „písala som si elektronický denník, ale nebudem pokračovat', radšej začnem kreslit““, „,nechcelo sa mi to písat' samej, tak sme si s priatel’om zaviedli spoločnú kroniku a to už potom bolo pekné“, „písala som si denníky a už ma nudia, tak som skúsila video denník, ale potom ked' som sa videla, začala som plakat' a strácat' sa v pocitoch“.

U niektorých študentov teda došlo k odklonu od pôvodného zadania, čo je však možné plne akceptovat', ked'že v rámci osobnostného rozvoja je plne adekvátne a vhodné podporovat' schopnost' naučit' sa samého seba plne akceptovat'. Je potrebné zdôraznit', že pri písaní terapeutických denníkov nie je nič nesprávne (Rainwater, 1993:92) - vrátane slobody v kombinovaní rôznych foriem zaznamenávania alebo spracúvania najvnútornejších súkromných pocitov (písanie, kreslenie, vpisovanie citátov, básní, lepenie fotografií, atd’.) alebo slobody v písaní gramatických chýb počas vedenia záznamov. 
Pokial' ide o poslednú z citovaných odoziev, tu by sme opätovne radi dali do pozornosti ponuku možnosti verbalizovat' a získat' spätnú väzbu v kontakte s kvalifikovaným a skúsenejším odborníkom, ktorý má poznatky z oblasti medicíny, psychoterapie a biblioterapie, ako sme to už spomenuli vyššie - čo so zaznamenaným a ako to prípadne d’alej spracovat' z novej perspektívy. Viacerí autori pri zaplavení pocitmi u pacientov alebo klientov, ktoré sa tzv. cyklia v procese písania a z ktorých akoby na prvý pohlad nie z problému východisko, ako napríklad pri posttraumatickej stresovej poruche, ponúkajú možnost' kontinuálneho prerušovania negatívneho zážitku pozitívnymi pocitmi, odloženia zážitku na filmové plátno a pustenia „,filmu pospiatky“, čím sa znižuje jeho emočný náboj (Conor a Seymour, 1998:53; Levin a Fredericková, 2002:171; Rothschild, 2007; Psychické prvá pomoc, 2008) alebo spracovania alebo popísania situácie zinej perspektivy, ako napriklad v 3 osobe jednotného čísla, čo pomáha zvládnut’ náhle návaly emócií (Pennebaker, 2013:101).

Na margo pozitívnych odoziev k písaniu terapeutického denníka, ako sme ich reprodukovali vyššie - je možno zaujímavé ešte poznamenat', že počas protiepidemiologických opatrení na ochranu pre Covid-19 bola v apríli 2020 na prevenciu duševných ochorení, domáceho násilia a samovrážd zriadenia Krízová linka prvej pomoci Covid-19 pre mladých, ktorá okrem mailového a chatového kontaktu umožňovala aj telefonické a video kontakty s odborníkmi. Počas doby trvania projektu bolo na tejto linke mladým l’ud'om poskytnutých 40880 poradenských a krízových komunikácií (Prvá psychologická pomoc, 2020).

Aj ked’ čo do kvantity sme iste len menšou mierou - ale čo do individuálneho významu dúfame dôležitou, aspoň trochu prispeli $\mathrm{k}$ ul’ahčeniu zvládania náročnejších životných situácií, $\mathrm{v}$ ktorých sa študenti ocitli $\mathrm{v}$ súvislosti s náhlou zmenou celospoločenských podmienok. Zozbierané a retrospektívne analyzované spätné väzby od študentov o vedení terapeutického denníka ukázali, že pri terapeutických denníkoch ide aj o účinnú preventívnu metódu na zvládanie náročných životných situácií.

Charakteristickým znakom liečebnej pedagogiky však je nielen individuálna starostlivost’ o osobu s nejakým životným problémom, ale napríklad v rámci včasnej intervencie aj súvisiaca starostlivost' o rodinu diet'at'a, prípadne o iné dôležité vzt'ahy jednotlivca $v$ širšom prostredí školy alebo komunity ako o prostredie a vzt’ahy podporujúce jeho rast a vývin. Ide o tzv. viacdimeñionálny prístup, ktorý okrem podpory konkrétnej osoby nachádzajúcej sa v st’aženej životnej situácii nefarmakologickými prostriedkami liečebnopedagogických intervencií zahŕňa aj úpravy $\mathrm{v}$ prostredí so súčasnou podporou rodinných príslušníkov alebo iných dôležitých vzt'ažných osôb osoby, prípadne učitel’ov a vychovávatel'ov. V prípade, že o dospelého, ide o podporu a posilňovanie vzt'ahov v inom obdobnom prostredí. Posledné výskumy ukazujú, že multidimenzionálna zdravotná starostlivost’ zahŕňajúca a okrem pacienta podporujúca aj jeho najbližšie okolie prináša celkove lepšie výsledky v jeho uzdravovaní a prospievaní (Kovácsová a kol., 2020).

Rovnaký princíp platí aj pri použití terapeutického denníka. $K$ jeho vedeniu pre vyššie popísané preukázané biologické, psychologické a sociálne účinky môžu byt' vedení nielen samotní pacienti s onkologickým alebo Alzheimerovým ochorením, ale aj ich príbuzní a iné osoby, ktoré sa starajú o ich opateru. Rovnako môže byt' prínosné viest' si terapeutický denník pre deti zo sociálne znevýhodneného rodinného prostredia (neúplné rodiny, ekonomické problémy, výchovné problémy...) ako aj d’alších môže profesionálny odborník - lekár, sestra, psychológ, 
liečebný pedagóg, logopéd, učitel', vychovávatel', sociálny pracovník, knihovník, atd'. motivovat' a sprevádzat' vo vedení terapeutického denníka, prostredníctvom ktorého môže spracovat' a zvládnut' mnohé potenciálne dlhodobo emočne zat’ažujúce životné udalosti. Uvedené odporúčanie sme síce v našom zadaní so študentami nerealizovali, ale aj tak sme dostali spätnú väzbu, že $v$ písaní terapeutického denníka boli potom priamo študentom povzbudzovaní aj rodinní príslušníci a toto zadanie by sa mohlo stat' súčast'ou nejakého obdobného zadania $\mathrm{v}$ blízkej budúcnosti.

\section{Diskusa a záver}

V biblioterapii zohráva osobitne významnú úlohu, aby sa príbeh dotýkal osobne dôležititej aktuálne výżnamnej témy pacienta s vysokým motivařným nábojom, oslovoval jebo túžby a želania s možnostou vybladania pozitivnych perspektiv. Terapeutický denník takúto možnost' ponúka. Terapia, výchova alebo prevencia sa prakticky vždy nejakým spôsobom dotýka identity konkrétneho človeka. Dobre spracované pôvodne zat’ažujúce obsahy spravidla ponúkajú odpovede na tieto otázky: Kto som? Kam patrím? Kam smerujem? Aký to má význam? Významnou čast'ou profesionálne vedeného terapeutického pôsobenia je, ako sme už vyššie spomenuli - možnost' zdiel'ania pokroku, ktorý vytvára priestor pre posilnenie ozdravných účinkov, napríklad aj tým, že sa využije prelínanie biblioterapeutických metód a techník s metódami a technikami z iných umeleckých ,art-terapií“ ako sú muzikoterapia, arteterapia, dramatoterapia, terapia pohybom (vrátane tanečnej terapie), alebo s terapiou hrou, ergoterapiou, atd’.

Ked’že písanie samozrejme nie je jedinou možnost'ou úplného sebavyjadrenia sa, niektorí jednotlivci lepšie profitujú z neverbálneho vyjadrovania emócií napríklad pohybom, hudbou, kresbou atd', alebo v ich kombinácii lepšie, ako by to neboli nikdy schopní vyjadrit' slovami. Napriek tomu sa aj pri týchto technikách a ich kombináciách po ich použití odporúča nájst' si vhodné miesto, zobrat' pero a papier a písomne zachytit' myšlienky a pocity z realizovaných aktivít (Pennebaker, 2013:149). Pri písaní sa odporúča zamerat' na to čo sa dialo s myslou a telom, čo bolo vyjadrované a ako sa to podarilo, čo si osoba uvedomila alebo sa dozvedela nové, ako jej to pomáha pochopit' jej emočné prežívanie a správanie, atd'. Písanie potom slúži ako nástroj na dodatočné štrukturovanie a pochopenie toho, čo sa udialo (ibid).

$\mathrm{V}$ spojení s ,čitatelnými“ vegetatívnymi, emočnými, intuitívnymi a inými prejavmi v prežívaní alebo správaní pacienta/klienta a ich následným kognitívnym spracovaním sú terapeutické denníky ako nástroj v biblioterapii v rukách skúseného biblioterapeuta bránou vedúcou k liečeniu a vyliečeniu, pretože individuálne vnímaný najvýznamnejší segment zážitku rovnako dobre odráža individuálny aktuálny stav, potreby, túžby, presvedčenia a ambície konkrétneho pacienta $\mathrm{v}$ stave „tu a teraz“, teda sa pracuje s aktuálne s najväčším motivačným nábojom.

Pomocou neho možno v biblioterapeutickom procese úspešne dekomponovat', porozumiet' a znovukonstruovat' - či už vývinovo alebo hlbšie fenomenologicky - celý konkrétny osobný príbeh alebo príbeh problému alebo ochorenia $\mathrm{v}$ inom kontexte alebo inej perspektíve (Pennebaker, 2013:101, 119) alebo $v$ novom šivotnom vzorci a to aj v prípade, že zmena je možná iba v podobe prijatia a akceptácie toho, čo je dané. Na tento účel napríklad už dlhé roky v biblioterapii slúži dnes už všeobecne známa metóda „dokončovania rozprávok/príbehov/básní atd’“ umožňujúca testovanie alebo „naprogramovanie“ potenciálnej novej životnej perspektívy alebo nového 
životného vzorca, ktoré spravidla nasledujú po biblioterapeutickom diagnostickom a terapeutickom procese spracovania dovtedajších zat’ažujúcich životných obsahov.

\section{Súpis zdrojov informácií:}

Brož, F. (2012, 15 mája) Psani jako cesta k uzdravení. Požičal si 07.02.2021 zo stránky: https://psychologie.cz/psani-jako-cesta-k-uzdraveni/

Conor, J., a Seymour, J. (1998). Úvod do neurolingvistickébo programování. Praha: Institut pro neurolingvistické programování.

Černá, L. (2019, 5 augusta). Denník nie je len pre pubert’ákov, ale ǔ̌itočná pomôcka na celý život. Požičal si 07.02.2021 zo stránky: https://tchiboblog.sk/preco-si-pisat-dennik/

Hartlová, H., a Hartl, P. (2009). Psychologický slovník. 2. vyd. Praha: Portál.

Howie, M. (1988). Reading therapy and the social worker. In: J. Clarke, E. Bostle (eds.) Reading Therapy. London: Library Association, p. 18-20. (v angličtine)

Indroop, D. (2019). Writting in your Journal/Diary. Požičal si 07.02.2021 zo stránky: https://slideplayer.com/slide/13161597/ (v angličtine)

Kotrbová, K. a kol. (2019). Veková struktúra lekárov na Slovensku. Modra: VEEVENT, s.r.o.

Kovácsová, E., Horňáková, M., Kotrbová, K. a Yakhyaev, Z. (2020). Starostlivost' o l’udí so spoluzávislost'ou. Schválené štandardné diagnostické a teerapentické postupy v odbore liečebná pedagogika. Bratislava: Ministerstvo zdravotníctva Slovenskej republiky.

Kováčová, B., a Valešová-Malecová, B. (2018). Biblioterapia v ranom a predškolskom veku. Bratislava: Univerzita Komenského.

Levin, P.A., a Fredericková, A. (2002). Prebúdz̧anie tigra. Liečenie traumy. 1. vyd. Humenné: Občianske združenie Pro Fammilia, Humenné.

Majzlanová, K. (2005). Uplatnenie biblioterapie u detí so špecifickými poruchami ǔ́enia [elektronický optický disk (CD-ROM)] In: V. Mezinárodní konference $\mathrm{k}$ problematice osob se specifickými potřebami. Olomouc: Univerzita Palackého v Olomouci.

Majzlanová, K. (2012). Biblioterapia a dramatoterapia ako nástroj intervencie pri zuyšovaní kvality života detí rodičov so psychickými poruchami. [elektronický optický disk (CD-ROM)], [s. 213-230]. Bratislava: Samosato.

Majzlanová, K. (2018). Uplatnenie expresivnych terapeutických prístupov u deti so špecifickeými edukačnými potrebami, 192-216. In: Harčaríková, T., Lopúchová, J. Teória a praxeológia výchovnej a komplexnej rehabilitácie. Brno: MSD.

Majzlanová, K. (2017). Základy biblioterapie pre knihovníkov. Banská Bystrica: Úrad Banskobystrického samosprávneho kraja a Krajská knižnica Ludovíta Štúra.

Majzlanová, K., a Kotrbová, K. (2019). Význam príbehu v biblioterapii, In: Bukor, J., Szimon, Sz. a kol. Zborník XI. Medzinárodnej vedeckej konferencie Univerzity J. Seleho 2019, Sekcia Jazyk-Kultúra-Vzt’ahy. Univerzita J. Selyeho Komárno. [s. 149-172]. Požičal si 19.01.2021 zo stránky: http://uk.ujs.sk/dl/books.html

Manzoni, G.M., Castelnuovo, G., \& Molinari, E. (2011). The Written-heart Study (expressive writing for heart healing): Rationale and Design of Randomized and Controlled Clinical Trial of Expressive Writting in Coronary Patients refered to Residential Cardiac 
Rehabilitation. Health and Quality of Life Outcomes Journal, Jul 8, 9:51. Požičal si 08.02.2021 zo stránky: https://pubmed.ncbi.nlm.nih.gov/21740564/ (v angličtine)

Milbury, K., Spelman, A., Wood, Ch., Matin, S. F., Tannir, N., Jonasch, E., Pisters, L., Wei, Q., \& Cohen, L. (2014). Randomized controlled trial of expressive writting for patients with renal cell carcinoma. Journal of Clinical Oncology, Mar 1, 32 (7), 663-70. Požičal si 08.02.2021 zo stránky: https://pubmed.ncbi.nlm.nih.gov/24470003/ (v angličtine)

Moor, C., Strener, J., Hall, M., Warneke, C., Gilani, Z., Amato, R., \& Cohen, L. (2020). A pilot study of the effects of expressive writing in a phase II trieal of vaccine therapy for metasatic renal cell carcinoma. Health Psychology Journal, 21, 616-619. Požičal si 08.02.2021 zo stránky https://pubmed.ncbi.nlm.nih.gov/12433015/ (v angličtine)

Obert, V. (1986). Cesty výchovy detského čitatela. 1. vyd. Bratislava: Mladé letá.

Pennebacker, J.W. (2004). Writing to Heal. A Guided Journal for Recovering from Trauma and Emotional Upheaval. Oakland: New Harbringer Publications, Inc. Požičal si 08.02.2021 zo stránky https://www.amazon.com/Writing-Heal-recovering-emotional-upheaval/dp/1572243651 (v angličtine)

Pennebaker, J.W. (2013). Writting to Heal. A Guided Journa for Recovering from Trauma and Emotional Upheaval. Wheat Ridge: Center for Journal Therapy, Inc. (v angličtine)

Pilarčíková-Hýblová, S. (1997) Biblioterapia. Liptovský Mikuláš: Vydané vlastným nákladom.

Prvá psychologická pomoc počas pandémie Covid-19. Bratislava: IPčko, 2. 12. 2020. Požičal si 09.02.2021 zo stránky https://ipcko.sk/prva-psychologicka-pomoc-pocas-pandemiecovid-19/

Psychická prvá pomoc, krízová intervencia a manažment stresu po zat’ažujúcich situáciách. Kniha textov. (2008). Pilotný projekt zavádzania psychickej prvej pomoci a psychotraumatologickej starostlivosti $\mathrm{v}$ záchrannej zdravotnej službe ITMS kód 131200110464. Bratislava: Ministerstvo zdravotníctva Slovenskej republiky; Operačné stredisko záchrannej zdravotnej služby Slovenskej republiky; Institut fur Psychologie, Arbeitsgruppe Notfallpsychologie Universität Insbruck; Osterreicisches Roters Kreutz; Transfér Slovensko, spol. s.r.o. Centrum vzdelávania manažérov.

Quian, J., Zhou, X., San, X., Wu, M., Sun, S., \& Yu, X. (2020). Effects of expressive writing intervention for women's PTSD, depression, anxiety and stress related to pregnancy: A meta-analysis of randomized controlled trials. Psychiatry Research, Jun, 2, 88:112933. Požičal si 07.02.2021 zo stránky https://pubmed.ncbi.nlm.nih.gov/32315889/ (v angličtine)

Rainwater, J. (1993). Vežmète そ̌ivot do vlastních rukou. 1. vyd. Grada Praha.

Rothschild, B. (2007). Pamät' tela. Psychofyzrológia a liě̌enie traumy. 1. vyd. Humenné: Pro Familia.

Shemesh, J. (2016, December 18). Príbeh Anny Frankovej bol možno iný. Neodhalil ju udavač, ale náhoda [online]. N Press, [cit. 2016-12-18]. Požičal si 07.02.2021 zo stránky https://dennikn.sk/636585/pribeh-anny-frankovej-bol-mozno-iny-ako-sme-si-doterazmysleli-neodhalil-ju-udavac-ale-nahoda/

Svoboda. P. (1988). Expresivně formativní terapie - biblioterapie. Arteterapie.

Svoboda, P. (2013). Biblioterapie. 1. vyd. Univerzita Palackého v Olomouci.

Thiele, C., Laireiter, A.-R., \& Baumann, U. (2020). Diaries in Clinical Psychology and Psychotherapy: A Selective Review. Clinical Psychology and Psychotherapy, 9, 1-37. Požičal si 
09.02.2021 zo stránky https://onlinelibrary.wiley.com/doi/abs/10.1002/cpp.302 (v angličtine)

\section{Poznámky:}

[1] Pozn. aut.: Vid' napríklad vyhl'adávacie klúčové slová v medzinárodnej odbornej medicínskej databáze PubMed. 